\title{
Maize and soybeans production in integrated system under no-tillage with different pasture combinations and animal categories ${ }^{1}$
}

\author{
Produção de milho e soja em sistema integrado sob plantio direto com diferentes \\ combinações de pastos e categorias animais
}

\author{
Hernani Alves da Silva ${ }^{2 *}$, Anibal de Moraes ${ }^{2}$, Paulo César de Faccio Carvalho ${ }^{3}$, Adriel Ferreira da Fonseca ${ }^{4}$ e \\ Carlos Tadeu dos Santos Dias ${ }^{5}$
}

\begin{abstract}
The adoption of no-till system (NTS) combined with crop-livestock integration (CLI) has been a strategy promoted in Brazil, aiming to maximize areas yield and increase agribusiness profitability. This study aimed to evaluate grains yield and phytotechnical attributes from maize and soybean culture by CLI system under NTS after winter annual pure and diversified pastures with the absence or presence of grazing animals. The experiment was installed in Castro (Paraná State, Brazil) on in a dystrophic Humic Rhodic Hapludox with a clay texture, using experimental design of randomized complete blocks in $4 \times 2$ factorial scheme with three replications. Treatments included four pasture combinations (diversified or pure) and animal categories (light and heavy) subjected or not to grazing animals during the winter. During 2008/09 and 2009/10 summers, the area was cultivated with soybeans and maize, respectively, with yield assessment of grains and phytotechnical attributes. Treatments did not alter the yield and weight of a thousand seeds (WTS) of soybeans. In maize culture, the grazing animal during the winter increased the plant population and grains yield, but gave slight decrease in WTS. Pasture combinations (diversified or pure) and animal categories (light and heavy) did not interfere in soybean culture, but benefited the maize crop.
\end{abstract}

Key words: Zea mays L. Glycine max (L.) Merrill. Crop-livestock system integration. Conservationist agriculture.

RESUMO - A adoção do sistema de plantio direto (SPD), aliado a integração lavoura pecuária (ILP) tem sido uma estratégia fomentada no Brasil, visando maximizar o rendimento das áreas e aumentar a lucratividade do agronegócio. O objetivo deste trabalho foi avaliar o rendimento de grãos e atributos fitotécnicos nas culturas de milho e soja, em sistema de ILP, sob plantio direto, após o cultivo de pastos anuais de inverno, puros ou diversificados, com ausência ou presença de animais em pastejo de diferentes categorias. O experimento foi instalado no município de Castro (PR), em um Latossolo Bruno distrófico textura argilosa, empregando-se delineamento experimental de blocos completos aleatorizados, em esquema fatorial 4 x 2, com três repetições. Os tratamentos incluíram quatro combinações de pastagens (diversificadas ou puras) e categorias de animais (leves e pesados), submetidas ou não ao pastejo animal durante o inverno. Durante o verão de 2008/09 e 2009/10 a área foi cultivada com soja e milho, respectivamente, e procederam-se avaliações de rendimento de grãos e atributos fitotécnicos. Os tratamentos não alteraram o rendimento e o peso de mil sementes (PMS) de soja. Na cultura do milho, o pastejo animal, durante o inverno, aumentou a população de plantas e o rendimento de grãos, mas proporcionou ligeira diminuição no PMS. As combinações de pastos (diversificados ou puros) e categorias de animais (leves e pesados) não interferiram na cultura da soja, mas beneficiaram a cultura do milho.

Palavras-chave: Zea mays L. Glycine max (L.) Merrill. Integração lavoura-pecuária. Agricultura conservacionista.

\footnotetext{
*Autor para correspondência

${ }^{1}$ Recebido para publicação em 09/08/2011; aprovado em 26/03/2012

Parte da Tese de Doutorado do primeiro autor apresentada ao Programa de Pós-Graduação em Agronomia (Área: Produção Vegetal), Universidade Federal do Paraná (UFPR)

${ }^{2}$ Departamento de Fitotecnia e Fitossanitarismo/Setor de Ciências Agrárias/Universidade Federal do Paraná/UFPR, Rua: Dos Funcionários 1540, Curitiba-PR, Brasil, 80.035-050, hernanialves@emater.pr.gov.br, anibalm@ufpr.br

${ }^{3}$ Departamento de Plantas Forrageiras e Agrometeorologia/Universidade Federal do Rio Grande do Sul, Porto Alegre-RS, Brasil, paulocfc@ufrgs.br ${ }^{4}$ Departamento de Ciência do Solo e Engenharia Agrícola/Setor de Ciências Agrárias e de Tecnologia/Universidade Estadual de Ponta Grossa, Ponta Grossa-PR, Brasil, adriel@uepg.br

${ }^{5}$ Departamento de Ciências Exatas/Escola Superior de Agricultura Luiz de Queiroz/Universidade de São Paulo, Piracicaba-SP, Brasil, ctsdias@ usp.br
} 


\section{INTRODUCTION}

Agribusiness represents an average $25 \%$ of Brazilian GDP - Gross Domestic Product (CENTRO DE ESTUDOS AVANÇADOS EM ECONOMIA APLICADA, 2008) and particularly in the region of Campos Gerais, where agricultural production accounts for $10.4 \%$ of Gross Value of crop-livestock Production (GVP) of Paraná State (VALOR ..., 2008). However, not all agricultural activities and livestock are managed under an integrated and sustainable way. In 2009/2010 summers, 702,000 ha in the region of Campos Gerais were cultivated with soybean [Glycine $\max (\mathrm{L}$.) Merrill], maize (Zea mays L.), and beans (Phaseolus vulgaris L). In winter, only $27 \%$ of this area was cultivated with grains production (SECREATARIADAAGRICULTURA E DO ABASTECIMENTO DO PARANÁ, 2010). The remaining area $(512,460$ ha) was left fallow or was planted with ground cover plants predominantly black oats (Avena strigosa Schreb) and annual ryegrass (Lollium multiflorum L.), which have high forage potential (MACARI et al., 2006).

Hence the importance of crop-livestock integration (CLI) in no-tillage system (NTS), which makes it an important alternative to occupy these areas and increase the sustainability of rural productions, providing: (i) biological and economic advantages (BALBINOT JUNIOR et al., 2009); (ii) enhancing and maximizing the exploitation land use (LANDERS, 2007); (iii) increasing yield and risks reduction (FONTANELI et al., 2006); (iv) carbon sequestration and reducing the emission of greenhouse gases - global warming effect - (CERRI et al., 2010). In Brazil southern, there is great potential for beef production in pure or mixed winter pastures (ASSMANN et al., 2004; NICOLOSO; LANZANOVA; LOVAZO, 2006). Also, there is high potential for milk production in annual winter pastures (black oats and annual ryegrass) associated with the decreased amount of concentrated supplementation (SILVA et al., 2008). Additionally, the appropriate animal grazing during the winter, CLI under NTS can result in: (i) increase in nutrients cycling particularly nitrogen and maize yield (ASSMANN et al., 2003); (ii) not changing both nodulation (FONTANELI et al., 2000) and soybean yield (NICOLOSO; LANZANOVA; LOVAZO, 2006). However, issues surrounding the soil-plant-animal system are not yet well understood, implying for more interdisciplinary research with different forages species and agricultural crops, animal categories, and pasture systems (BALBINOT JUNIOR et al., 2009).

In this experiment with grazing of dairy heifers on a large scale, the hypothesis was tested about the presence of animals in appropriate charges, which does not affect both the production of forage biomass in winter and subsequent crop yields, grains producers. This study aimed to evaluate the grain yield and phytotechnical attributes in soybean and maize crops in CLI system under no-tillage, after winter annual pure and diversified pastures with the absence or presence of grazing animals.

\section{MATERIAL AND METHODS}

\section{Experiment localization, area history, and edafoclimatic characterization}

This experiment was performed at the Heifer Production Unit of the Castrolanda Agricultural Cooperative (latitude: 2447'28' S, longitude: $50^{\circ} 00^{\prime} 25^{\prime} \mathrm{W}$, and average altitude: $1,005 \mathrm{~m}$ ) in the municipality of Castro (Paraná State, Brazil). The experimental area is located in the physiographic region called Primeiro Planalto Paranaense with a climate of $\mathrm{Cfb}$ type humid subtropical in the Köppen classification; this region has mild summers and winters with severe and frequent freezing, and it does not have a defined dry season (INSTITUTO AGRONÔMICO DO PARANÁ, 1994). In the Table 1 is presented the temperature and precipitation values during the experimental period (from September/2008 to April/2010). According to Empresa Brasileira de Pesquisa Agropecuparia/Fundação ABC (2001), the predominant soil in the experimental area is dystrophic Humic Rhodic Hapludox with a clay texture, with a gently undulating relief ( 2 to $4 \%$ ), and sand, clay, and silt concentrations of 384,439 , and $177 \mathrm{~g} \mathrm{~kg}^{-1}$, respectively.

The area for experiment has been managed in NTS since 2003, cultivating maize or soybeans for grains production in the spring/summer, and annual ryegrass and/ or black oats for grazing animals (dairy heifers) during the fall/winter. In maize crops, $300 \mathrm{~kg} \mathrm{ha}^{-1}$ of 10-20-20 $\left(\mathrm{N}-\mathrm{P}_{2} \mathrm{O}_{5}-\mathrm{K}_{2} \mathrm{O}\right.$ ) formulated were used at the time of sowing and $400 \mathrm{~kg} \mathrm{ha}^{-1}$ of 22-00-21 formulated as top dressing. In soybean crops, $300 \mathrm{~kg} \mathrm{ha}^{-1}$ of 00-20-20 formulated were used at the time of sowing and $150 \mathrm{~kg} \mathrm{ha}^{-1}$ of potassium chloride $\left(60 \% \mathrm{~K}_{2} \mathrm{O}\right)$ as top dressing.

In addition, $50 \mathrm{~m}^{3} \mathrm{ha}^{-1}$ year-1 of pig manure was applied prior to 2008, and in July 2009, surface application, without incorporation, of dolomitic limestone began at a dosage of $3.0 \mathrm{Mg} \mathrm{ha}^{-1}$ with an effective calcium carbonate equivalent of the lime (ECCE), calcium oxide $(\mathrm{CaO})$, and magnesium oxide $(\mathrm{MgO})$ of 898,286 , and $195 \mathrm{~g} \mathrm{~kg}^{-1}$, respectively. The area main chemical attributes at the time of experiment deployment are shown in Table 2 . 
Table 1 - Rainfall monthly mean, maximum temperature (maxT), minimum temperature (minT), and medium temperature (medT) during the experiment (September/2008 to April/2010) in the municipality of Castro (Paraná State, Brazil)

\begin{tabular}{|c|c|c|c|c|c|c|c|c|c|}
\hline \multirow{2}{*}{ Attribute/Month } & \multicolumn{8}{|c|}{$2008 / 2009$} & \multirow{2}{*}{ Medium } \\
\hline & Spt & Oct & Nov & Dec & Jan & $\mathrm{Feb}$ & Mar & Apr & \\
\hline Rainfall, mm & 48.5 & 177.0 & 164.9 & 76.6 & 248.5 & 215.0 & 77.8 & 21.1 & 128.7 \\
\hline $\operatorname{maxT},{ }^{\circ} \mathrm{C}$ & 20.3 & 22.1 & 23.6 & 26.1 & 24.3 & 26.6 & 27.0 & 24.8 & 24.4 \\
\hline $\operatorname{minT},{ }^{\circ} \mathrm{C}$ & 9.7 & 14.1 & 14.3 & 13.9 & 15.9 & 17.0 & 15.9 & 12.9 & 14.2 \\
\hline $\operatorname{medT},{ }^{\circ} \mathrm{C}$ & 14.4 & 17.5 & 18.0 & 19.2 & 19.3 & 20.8 & 20.6 & 17.9 & 18.5 \\
\hline \multicolumn{10}{|c|}{$2009 / 2010$} \\
\hline Rainfall, mm & 222.7 & 181.2 & 115.7 & 124.3 & 191.4 & 110.5 & 122.2 & 108.8 & 147.1 \\
\hline $\max \mathrm{T},{ }^{\circ} \mathrm{C}$ & 21.8 & 23.4 & 28.0 & 26.7 & 26.4 & 27.4 & 26.2 & 23.5 & 25.4 \\
\hline $\operatorname{minT},{ }^{\circ} \mathrm{C}$ & 12.8 & 13.7 & 17.8 & 16.9 & 17.7 & 18.1 & 16.5 & 13.2 & 15.8 \\
\hline medT, ${ }^{\circ} \mathrm{C}$ & 16.9 & 18.1 & 22.8 & 21.5 & 22.1 & 22.7 & 21.3 & 18.4 & 20.5 \\
\hline
\end{tabular}

Source: ABC Foundation's weather station, located approximately $5.0 \mathrm{~km}$ far from the experiment localization

Table 2 - Soil chemical attributes at the time of the experiment

\begin{tabular}{|c|c|c|c|c|c|c|c|c|c|c|c|}
\hline Block & Layer & $\mathrm{pH}\left(\mathrm{CaCl}_{2}\right)$ & $\mathrm{H}+\mathrm{Al}$ & $\mathrm{Al}$ & $\mathrm{Ca}$ & $\mathrm{Mg}$ & $\mathrm{K}$ & $P^{(1)}$ & $\mathrm{TOC}^{(2)}$ & $\mathrm{TN}^{(3)}$ & $\mathrm{V}^{(4)}$ \\
\hline & $\mathrm{cm}$ & & - & - & $\mathrm{ol}_{\mathrm{c}} \mathrm{c}$ & - & ---- & $\mathrm{mg} \mathrm{dm}^{-3}$ & $---g^{\prime}$ & -3 ----- & $\%$ \\
\hline \multirow{2}{*}{1} & $0-10$ & 5.1 & 75 & 0 & 58 & 16 & 6 & 52.3 & 36.8 & 2.3 & 51 \\
\hline & $10-20$ & 4.8 & 86 & 1 & 51 & 15 & 7 & 131.9 & 38.7 & 1.8 & 46 \\
\hline \multirow{2}{*}{2} & $0-10$ & 5.0 & 78 & 0 & 53 & 20 & 6 & 72.9 & 38.7 & 2.6 & 50 \\
\hline & $10-20$ & 4.8 & 95 & 2 & 43 & 16 & 6 & 101.3 & 35.4 & 1.9 & 41 \\
\hline \multirow{2}{*}{3} & $0-10$ & 5.2 & 76 & 0 & 62 & 16 & 7 & 76.7 & 36.8 & 2.4 & 53 \\
\hline & $10-20$ & 4.8 & 97 & 2 & 53 & 15 & 8 & 172.2 & 32.1 & 2.2 & 41 \\
\hline
\end{tabular}

${ }^{(1)}$ Available P by Mehlich-1 solution, ${ }^{(2)}$ TOC: total organic carbon, ${ }^{(3)} \mathrm{TN}$ : total nitrogen, ${ }^{(4)} \mathrm{V}$ : bases saturation

\section{Experimental design, treatments, and experiment management}

The experiment began at the pasture cycle of autumn-winter, in June/2008. The experimental design was completely randomized blocks in $4 \times 2$ factorial scheme with three replications. Treatments included four combinations of pastures and animals categories (dairy heifers), submitted or not to grazing.

During the winter, four treatments were studied: Cl - light animals (192 $\pm 40.9 \mathrm{~kg}$ of body weight and age of $9.4 \pm 2.31$ months) on diversified pasture composed by common annual ryegrass, common black oats, white clover (Trifolium repens L.), and red clover (Trifolium pratense L.); $C 2$ - heavy animals ( $278 \pm 41.2 \mathrm{~kg}$ of body weight and age of $19.6 \pm 2.47$ months) on diversified pasture; $C 3$ - light animals on pure pasture consisting of annual ryegrass, and; $C 4$ - heavy animals on pure annual ryegrass pasture.
Treatments pickets with light and heavy animals had $1.2( \pm 0.42)$ and $1.4( \pm 0.59)$ ha, respectively. In each plot, control areas were isolated with electric fence (5 $\times 10 \mathrm{~m}$ size) that received no grazing. During the experimental period, animals also received water "ad libitum" and energetic mineralized salt at the proportion of 100 grams per $100 \mathrm{~kg}$ of body weight per day.

The diverse winter pasture was sown on May $15^{\text {th }} 2008$ (sixty days after maize harvest), using $17 \mathrm{~cm}$ row spacing. Simultaneously, annual ryegrass, black oats, white clover, and red clover sowings were done of $50,80,1.7$, and $2.0 \mathrm{~kg} \mathrm{ha}^{-1}$, respectively. Pure pasture (annual ryegrass) was sown on May $12^{\text {th }} 2008$, using $80 \mathrm{~kg} \mathrm{ha}^{-1}$ of annual ryegrass seeds (common) and the same row spacings.

On May 6, 2009, annual ryegrass seeds (common), black oats, white clover, and red clover were sown, using 60, 60, 4, and $8 \mathrm{~kg} \mathrm{ha}^{-1}$, respectively 
for diversified pasture. It is noted that the clover seeds were inoculated with Rhizobium leguminosarum bv. Trifolii and pelleted. The pure ryegrass pasture was sown on May 5, using $60 \mathrm{~kg} \mathrm{ha}^{-1}$ of seeds. Fertilizations for both pasture types were carried out in (i) 12 and $76 \mathrm{~kg} \mathrm{ha}^{-1}$ of $\mathrm{N}$ and $\mathrm{P}_{2} \mathrm{O}_{5}$ doses, respectively in the sowing furrow, (ii) 54 and $54 \mathrm{~kg} \mathrm{ha}^{-1}$ of $\mathrm{N}$ and $\mathrm{K}_{2} \mathrm{O}$, respectively sixteen days after emergence (DAE).

Grazing method of continuous stocking was adopted, using put and take technique (MOTT; LUCAS, 1952), keeping four experimental animals fixed of Dutch Black Pied (DBP) and DBP and Jersey crosses per plot with a variable number of regulators animals. The adjustment of stocking was performed weekly, entering or removing regulators animals after measuring the pasture height in order to maintain the grass average height of $20 \mathrm{~cm}$ (CARVALHO, 2005). Height measurements were made weekly randomly (100 samples per plot), using sward stick (BARTHRAM, 1985).

Experimental animals left the area on October 22, 2008, totaling eighty-nine days of grazing. Then, the pasture drying was done with glyphosate at $1,440 \mathrm{~g} \mathrm{ha}^{-1}$ dose of active ingredient (a.i.). At thirty-three days after desiccation, soybean cultivar CD 205 sowing was performed, using $40 \mathrm{~cm}$ row spacing and fertilizer in the sowing furrow of $300 \mathrm{~kg} \mathrm{ha}^{-1}$ of 00-20-20 formulated $\left(\mathrm{N}-\mathrm{P}_{2} \mathrm{O}_{5}-\mathrm{K}_{2} \mathrm{O}\right)$. Soybean seeds were inoculated with selected strains of Bradyrhizobium.

The animals were removed from the experimental area on October 05, 2009, totaling eighty-eight days of grazing. Then, pasture desiccation was done with glyphosate at $1,200 \mathrm{~g} \mathrm{ha}^{-1}$ dose of a.i. At twenty-five days after animals' removal, maize sowing was done (ATL 200 modified simple hybrid), using $80 \mathrm{~cm}$ row spacing. Basic fertilization was carried out alongside the sowing furrow, using $320 \mathrm{~kg} \mathrm{ha}^{-1}$ of $10-20-20$ formulated $\left(\mathrm{N}-\mathrm{P}_{2} \mathrm{O}_{5}-\mathrm{K}_{2} \mathrm{O}\right)$. Maize final stand was of 66,536 plants $\mathrm{ha}^{-1}$. Top dressing was done in total area at 18 DAE (when the culture was at the V4 stage) at $400 \mathrm{~kg} \mathrm{ha}^{-1}$ dose of 22-00-21 formulated $\left(\mathrm{N}-\mathrm{P}_{2} \mathrm{O}_{5}-\mathrm{K}_{2} \mathrm{O}\right)$. Other cultural practices were used in both cultures of maize and soybeans in order to allow for appropriate growth and development.

\section{Evaluations and statistical analysis}

In soybean crop (2008/09), grains yield was evaluated by harvesting manually four center lines of $4.0 \mathrm{~m}\left(7.2 \mathrm{~m}^{2}\right.$ of area) per plot, processing, weighing, and moisture correction to $130 \mathrm{~g} \mathrm{~kg}^{-1}$ and also the weight of a thousand seeds (WTS). In maize crop (2009/10), the following attributes were evaluated: (i) plant population, (ii) grains yield by harvesting manually four central rows of $4.0 \mathrm{~m}$ (area of $12.8 \mathrm{~m}^{2}$ ) per plot, processing, weighing, and correction of moisture to $130 \mathrm{~g} \mathrm{~kg}^{-1}$, (iii) WTS, (iv) percentage of damaged kernels.

Results were analyzed by univariate statistics according to experiment model in completely randomized blocks in $4 \times 2$ factorial scheme. When $\mathrm{F}$ was significant $(\mathrm{P}<0.05)$, the means were compared by Tukey test $(\alpha=0.05)$. When there was no significant interaction among pasture combinations and animal categories (A Factor), subjected or not to grazing animals (B Factor), treatments effects were compared by observations average. All statistical analyzes were performed by SAS version 9.1 statistical program (SAS, 2004).

\section{RESULTS AND DISCUSSION}

At the experiment time, experimental units had high fertility (Table 2), due to the area management history and constant additions of organic (pig manure), mineral, and corrective fertilizers. This situation associated with NTS implementation and consolidation resulted over the years to high concentrations of available calcium, magnesium, potassium, and phosphorus, improvement of soil acidity, and high concentrations of total organic carbon and total nitrogen (Table 2). These attributes have provided the high productive capacity of the area, both for grain crops and forage plants.

During 2008 and 2009 winter, pastures (diversified or pure) were used in continuous grazing, using proper management strategy. These pastures have provided appropriate AWG (average weight gain) [values above the range of 800-900 $\mathrm{g} \mathrm{day}^{-1}$ (NATIONAL RESEARCH COUNCIL, 2001)] for tested animals (light and heavy), with an average stocking rate of $1,029 \mathrm{~kg} \mathrm{ha}^{-1}$ of live weight (Table 3 ).

The pasture in this period showed an average growth rate of $58 \mathrm{~kg} \mathrm{ha}^{-1}$ day $^{-1}$ of dry matter (DM), with average forage mass of $2,673 \mathrm{~kg} \mathrm{ha}^{-1}$ and production of forage accumulated of $6,549 \mathrm{~kg} \mathrm{ha}^{-1}$ of DM (Table 3). Whereas, for NTS maintenance in Brazil southern, an annual input of approximately $8,000 \mathrm{~kg} \mathrm{ha}^{-1}$ of DM is needed (MIELNICZUK et al., 2003). The amount of winter residual biomass in this study (Table 3 ) can be considered suitable for the adopted production system, which includes alternate croppings of soybeans and maize in the summer.

There were no interactions among pasture combinations and animal categories with presence or absence of grazing during the winter for all the studied plants attributes (Table 4). Treatments that were used did not cause changes in the grains yield and soybean WTS (Figure 1). Obtaining higher yields than $2,800 \mathrm{~kg} \mathrm{ha}^{-1}$ of 
Table 3 - Treatments characteristics used during the winter annual pasture, average and standard deviation data for 2008 and 2009

\begin{tabular}{lcccc}
\hline \multicolumn{1}{c}{ Attribute } & $\mathrm{C} 1$ & $\mathrm{C} 2$ & $\mathrm{C} 3$ & $\mathrm{C} 4$ \\
\hline Stocking rate $\left(\mathrm{kg} \mathrm{ha}^{-1}\right)$ & $1,003 \pm 108$ & $1,145 \pm 315$ & $849 \pm 71$ & $1,122 \pm 312$ \\
Growth rate $\left(\mathrm{kg} \mathrm{DM} \mathrm{ha}^{-1} \mathrm{day}^{-1}\right)$ & $55 \pm 22$ & $60 \pm 17$ & $57 \pm 22$ & $61 \pm 21$ \\
Forage mass $\left(\mathrm{kg} \mathrm{DM} \mathrm{ha}^{-1}\right)$ & $2,354 \pm 821$ & $2,860 \pm 1288$ & $2,832 \pm 920$ & $2,647 \pm 1147$ \\
Forage accumulated yield $\left(\mathrm{kg} \mathrm{DM} \mathrm{ha}^{-1}\right)$ & $6,468 \pm 1110$ & $7,240 \pm 1362$ & $6,055 \pm 1003$ & $6,426 \pm 1025$ \\
Final residue $\left(\mathrm{kg} \mathrm{DM} \mathrm{ha}^{-1}\right)$ & $2,304 \pm 1213$ & $2,705 \pm 1746$ & $3,143 \pm 1161$ & $2,732 \pm 1491$ \\
Height $(\mathrm{cm})$ & $26 \pm 7$ & $34 \pm 15$ & $32 \pm 7$ & $28 \pm 10$ \\
\hline
\end{tabular}

C1: diverse pastures (black oats, annual ryegrass, white clover, and red clover) under grazing by light animals (192 $\pm 40.9 \mathrm{~kg}$ ); C2: diverse pastures under grazing by heavy animals ( $278 \pm 41.2 \mathrm{~kg}$ ), C3 : pure pastures (annual ryegrass) under grazing by light animals, C4: pure pasture under grazing by heavy animals. DM: dry matter

Table 4 - F values of evaluated attributes in soybean (2008/09) and maize (2009/10) croppings, in a completely randomized blocks experiment in $4 \times 2$ factorial scheme

\begin{tabular}{|c|c|c|c|c|}
\hline \multirow{2}{*}{ Variation } & \multicolumn{4}{|c|}{ Soybeans } \\
\hline & \multicolumn{2}{|c|}{-------------Grains yield------------ } & \multicolumn{2}{|c|}{--------------------Weight of 1,000 seeds------------------ } \\
\hline A factor & \multicolumn{2}{|c|}{$0.75^{\mathrm{NS}}$} & \multicolumn{2}{|r|}{$1.67^{\mathrm{NS}}$} \\
\hline B factor & \multicolumn{2}{|c|}{$2.58^{\mathrm{NS}}$} & \multicolumn{2}{|r|}{$0.28^{\mathrm{NS}}$} \\
\hline \multirow[t]{3}{*}{ A factor vs. B factor } & \multicolumn{2}{|c|}{$0.47^{\mathrm{NS}}$} & \multicolumn{2}{|r|}{$0.33^{\mathrm{NS}}$} \\
\hline & \multicolumn{4}{|c|}{ Maize } \\
\hline & Grains yield & Plants population & Weight of 1,000 seeds & Percentage of damaged kernels \\
\hline A factor & $1.04^{\mathrm{NS}}$ & $2.62^{\mathrm{NS}}$ & $9.40 * *$ & $0.63^{\mathrm{NS}}$ \\
\hline B factor & $11.42 * *$ & $10.51 * *$ & $18.36^{* *}$ & $0.42^{\mathrm{NS}}$ \\
\hline A factor vs. B factor & $0.86^{\mathrm{NS}}$ & $0.59^{\mathrm{NS}}$ & $2.90^{\mathrm{NS}}$ & $0.23^{\mathrm{NS}}$ \\
\hline
\end{tabular}

Factor A: pastures and livestock category combination ( $C l$ - light animals in composed and diverse pasture of annual ryegrass, black oats, white clover, and red clover; $C 2$ - heavy animals in diversified pasture; $C 3$ - light animals in composed and pure pasture ryegrass; $C 4$ - heavy animals in pure pasture of annual ryegrass); $\mathrm{B}$ factor: presence or absence of animals grazing during the winter; *: $\mathrm{P}<0.05$; **: $\mathrm{P}<0.01$; ${ }^{\text {Ns}}$ : not significant

soybeans in the summer has been common when animal grazing during the winter (in a similar manner to that performed in this study) is well carried out, as reported in Nicoloso, Lanzanova e Lovato (2006) and Flores et al. (2007) works.

Treatments did not have effect on WTS what is consistent with the change in grains yield. Observed WTS values in this study are lower than those reported by Lunardi et al. (2008). However, these last authors obtained average yields of grains smaller than those observed in this study and also worked with another soybean cultivar.

The pasture and animal categories combinations have changed WTS, but did not affect plants population attributes, percentage of damaged kernels, and maize grains yield (Figure 2). Major and minor WTS were observed in $\mathrm{C} 3$ and $\mathrm{C} 1$ treatments, respectively. No differences were observed among WTS for treatments of $\mathrm{C} 1$ and $\mathrm{C} 2, \mathrm{C} 2$ and $\mathrm{C} 4$, and $\mathrm{C} 3$ and $\mathrm{C} 4$ (Figure 2). Despite being significant, these effects were not enough to provide change in grains yield (Figure 2).

In maize, animal grazing during the winter resulted in (i) higher plant population and grains yield, (ii) a slight decrease in WTS and no change in damaged kernels percentage (Figure 2). The highest grains yield was partly due to higher plant population that consequently may have resulted in more ears and grains production per area, but slightly lighter. However, WTS reduction was not enough to influence the crop yield. Scheeren et al. (2004) found that maize grains 
Figure 1 - Effects of pasture and animal categories combination with presence or absence of grazing during the winter on grains yield and weight of soybeans thousand seeds (WTS). C1: light animals on diversified pasture composed by annual ryegrass, black oats, white clover, and red clover. C2: heavy animals on diversified pasture. C3: light animals on pure pasture composed of annual ryegrass. C4: heavy animals on pure pasture of annual ryegrass. WG: with animals grazing. NG: No animal grazing. Lowercase letters are for combinations and uppercase letters are for pasture and do not differ statistically by Tukey test $(\alpha=0.05)$
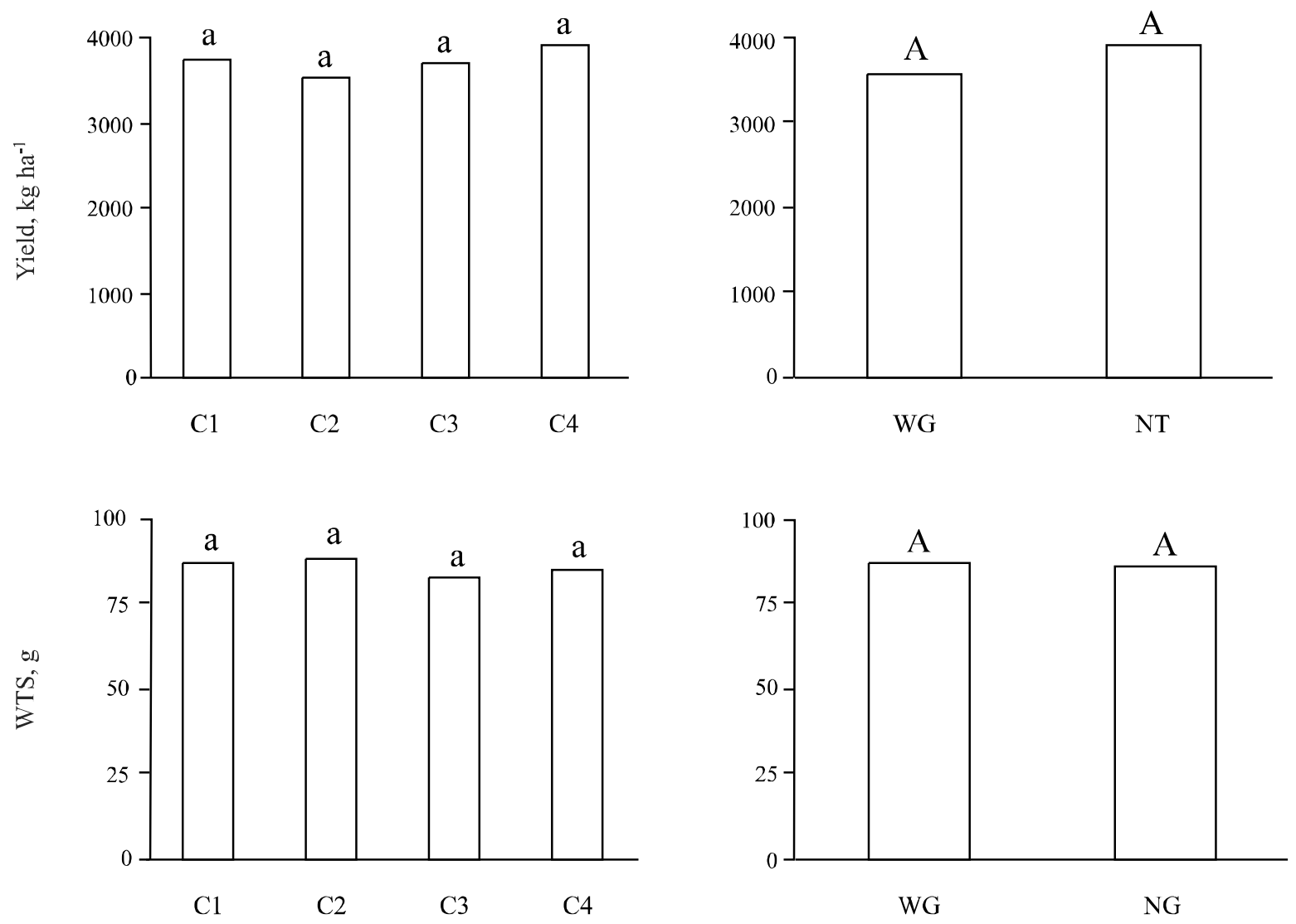

yield is directly related to plant population. Another factor that may have contributed to the higher yield of maize grown after animal grazing is the improvement in nutrients cycling particularly nitrogen. Assmann et al. (2003) observed that the maize crop in integrated production system increased grains yield in grazed areas during the winter. In CLI system (as adopted in this study), the animal has the ability to modify the nutrient cycling dynamics, something that occurs less significantly in systems where the forage is grown solely for the purpose of soil cover (CARVALHO et al., 2010).

The increasing population of maize plants due to animals grazing during the winter (Figure 2) can be attributed to proper pasture management and animal in the experimental area, providing major renovation of the root system and more uniform distribution of residual phytomass (CARVALHO et al., 2011). Probably,

as the animals fed the grass leaves, part of the root system died, improving soil physical characteristics and favoring the germination, emergence, and maize development.

Khurshid et al. (2006) found positive effects in improving the soil physical attributes due to vegetation cover management on maize growth and yield. In CLI under NT, moderate grazing in winter annual pastures improve aggregation (SOUZA et al., 2010a) and soil biological attributes (SOUZA et al., 2010b), benefiting subsequent crops (SILVA et al., 2000).

In general, observed WTS values in this study are similar to those reported by Scheeren et al. (2004). Damaged kernels percentage observed in this experiment are consistent with those reported in Casa et al. (2007). Maize population and yield are according to characteristics of hybrid that are higher than national averages. 
Figure 2 - Effects of pasture and animal categories combination with presence or absence of grazing during the winter on plant population, grains yield, weight of thousand seeds (WTS), and percentage of maize damaged kernels (MDK). C1: light animals on diversified pasture composed by annual ryegrass, black oats, white clover, and red clover. C2: heavy animals on diversified pasture. C3: light animals on pure pasture composed by annual ryegrass. C4: heavy animals on pure pasture of annual ryegrass. WG: with animals grazing. NG: No animal grazing
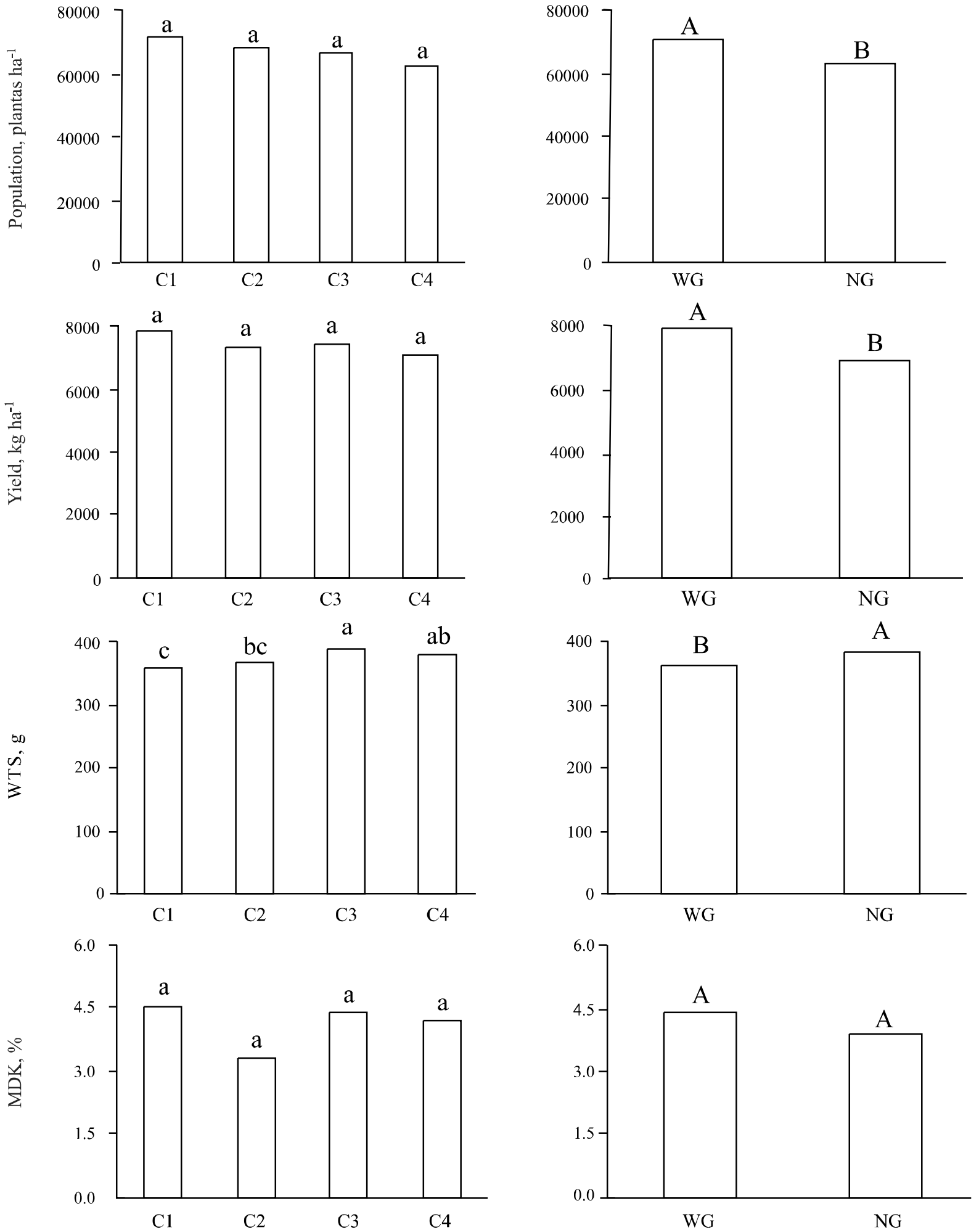


\section{CONCLUSIONS}

1. Pasture (pure and diverse) and animal categories (light and heavy) combinations with presence and absence of grazing did not alter the yield and weight of soybeans thousand seeds;

2. In maize crop, pasture and animal categories combinations did not affect plant population attributes and yield and percentage of damaged kernels. The animal grazing during the winter, despite having provided a slight decrease in weight of thousand seeds of maize, caused increase in the plant population and grains yield.

\section{ACKNOWLEDGMENTS}

To Castrolanda Agricultural Cooperative by disposing the area and animals during the experimental period. For also financial support to carry out experimental evaluations and funding for necessary laboratory analysis. To Conselho Nacional de Desenvolvimento Científico e Tecnológico - CNPq for financial support, which enabled the scholarship payment to a graduate student who assisted in data collection.

\section{REFERENCES}

ASSMANN, A. L. et al. Produção de gado de corte e acúmulo de matéria seca em sistema de Integração Lavoura-Pecuária em presença e ausência de trevo branco e nitrogênio. Revista Brasileira de Zootecnia, v. 33, n. 01, p. 37-44, 2004.

ASSMANN, T. S. et al. Rendimento de milho em área de integração lavoura-pecuária sob o sistema plantio direto, em presença e ausência de trevo branco, pastejo e nitrogênio. Revista Brasileira de Ciência do Solo, v. 27, n. 04, p. 675683, 2003.

BALBINOT JUNIOR, A. A. et al. Integração lavoura-pecuária: intensificação de uso de áreas agrícolas. Ciência Rural, v. 39, n. 06 , p. 1925-1933, 2009.

BARTHRAM, G. T. Experimental techniques: the HFRO sward stick. Aberdeen: Hill Farming Research Organization/ Biennial Report, 1985. p. 29-30.

CARVALHO, P. C. F. O Manejo da pastagem como gerador de ambientes pastoris adequados à produção animal. In: SIMPÓSIO SOBRE MANEJO DA PASTAGEM, 22., 2005, Piracicaba City. Anais ... Piracicaba City, 2005. p. 07-32.

CARVALHO, P. C. F. et al. Managing pasture animals to achieve nutrient cycling and soil improvement in no-till integrated systems. Nutrient Cycling in Agroecosystems, v. 88 , n. 02 , p. $259-273,2010$.
CARVALHO, P. C. F. et al. Integração soja-bovinos de corte no Sul do Brasil. Porto Alegre: Gráfica RJR Ltda, 2011. 60 p. (Boletim Técnico).

CASA, R. T. et al. Incidência de podridões do colmo, grãos ardidos e rendimento de grãos em híbridos de milho submetidos ao aumento na densidade de plantas. Summa Phytopathologica, v. 33, n. 04, p.353-357, 2007.

CENTRO DE ESTUDOS AVANÇADOS EM ECONOMIA APLICADA (CEPEA). PIB do agronegócio, 2008. Available at: <http://www.cepea.esalq.usp.br/pib/other/Cepea_PIB_ BR\%201994\%202008.xls>. Accessed on: 1 dec. 2010.

CERRI, C. C. et al. Review: Greenhouse gas mitigation options in Brazil for land-use chance, livestock and agriculture. Scientia Agrícola, v. 67, n. 01, p. 102-116, 2010.

EMPRESA BRASILEIRA DE PESQUISA AGROPECUÁRIA/ FUNDAÇÃO ABC. Levantamento semidetalhado de solos: Municipality of Castro. Internal Report. EMBRAPA/SOLOS; EMBRAPA/FLORESTAS, FUNDAÇÃO ABC, Castro City Parana State, Brazil, 2001. 86 p.

FLORES, J. P. C. et al. Atributos físicos do solo e rendimento de soja em sistema de plantio direto em integração lavourapecuária com diferentes pressões de pastejo. Revista Brasileira de Ciência do Solo, v. 31, n. 04, p. 771-780, 2007.

FONTANELI, R. S. I. Rendimento e nodulação de soja em diferentes rotações de espécies anuais de inverno sob plantio direto. Pesquisa Agropecuária Brasileira, v. 35, n. 02, p. 349-355, 2000.

FONTANELI, R. S.; SANTOS, H. P.; MORI, C. Lucratividade e risco de produção de grãos com pastagens, sob sistema plantio direto. Ciência Rural, v. 36, n. 01, p. 51-57, 2006.

INSTITUTO AGRONOMICO DO PARANÁ. Cartas climáticas do Estado do Paraná 1994. Londrina, PR., 1994. 49 p. (Documento, 18).

KHURSHID, K. et al. Effect of tillage and mulch on soil physical properties and growth of maize. International Journal of Agriculture \& Biology, v. 08, n. 05, p. 593-596, 2006.

LANDERS, J. N. Tropical crop-livestock systems in conservation agriculture: the Brazilian experience. Rome: Food and Agriculture Organization of the United Nations, 2007. 95 p.

LUNARDI, R. et al. Rendimento de soja em sitema de integração lavoura-pecuária: efeito de métodos e intensidades de pastejo. Ciência Rural, v. 38, n. 03, p. 795-801, 2008.

MACARI, S. et al. Avaliação da mistura de cultivares de aveia preta (Avena strigosa Schreb) com azevém (Lolium multiflorum Lam.) sob pastejo. Ciência Rural, v. 36, n. 03, p. 910-915, 2006.

MIELNICZUK, J. et al. Manejo de solo e culturas e sua relação com os estoques de carbono e nitrogênio do solo. In: CURI, N. et al. (Ed.). Tópicos em ciência do solo. Viçosa: Sociedade Brasileira de Ciência do Solo, 2003. p. 209-248. v. 03.

MOTT, G. O.; LUCAS, H. L. The design, conduct and interpretation of pasture trials on cultivated and improved pastures. In: INTERNATIONAL GRASSLAND CONGRESS, 
6., 1952, Pennsylvania. Proceedings... Pennsylvania: State College Press, 1952. p. 1380-1385.

NATIONAL RESEARCH COUNCIL. Nutrient requirements of dairy cattle, $17^{\text {th }}$ ed. Washington, D.C.: National Academy Press, 2001.

NICOLOSO , R. S.; LANZANOVA, M. E.; LOVATO, T. Manejo das pastagens de inverno e potencial produtivo de sistemas de integração lavoura-pecuária no Estado do Rio Grande do Sul. Ciência Rural, v. 36, n. 06, p. 1799-1805, 2006.

SAS SYSTEM. SAS Online Doc® 9.1.2. Cary, NC: SAS Institute, 2004.

SCHEEREN, B. R. et al. Arranjo populacional para a cultura do milho na região central do Estado do Mato Grosso do Sul. Acta Scientiarum: Agronomy, v. 26, n. 02, p. 55-60, 2004.

SECRETARIA DAAGRICULTURA E DO ABASTECIMENTO DOPARANÁ. Comparativodeárea,produçãoe produtividade no Paraná nas safras 08/09 e 09/10. Available at: <http:// www.seab.pr.gov.br/arquivos/File/deral/pss.xls\#Paraná!A1>. Accessed on: 1 dec. 2010.
SILVA, V. R.; REINERT, D.; REICHERT, J. M. Densidade do solo, atributos químicos e sistema radicular do milho afetados pelo pastejo e manejo do solo. Revista Brasileira de Ciência do Solo, v. 24, p. 191-199, 2000.

SILVA, H. A. et al. Análise da viabilidade econômica da produção de leite a pasto e com suplementos na região dos Campos Gerais, Paraná. Ciência Rural, v. 38, n. 02, p. 445450, 2008.

SOUZA, E. D. et al. Soil aggregation in a crop-livestock integration system under no-tillage. Revista Brasileira de Ciência do Solo, v. 34, p. 1365-1374, 2010a.

SOUZA, E. D. et al. Biomassa microbiana do solo em sistema de integração lavoura-pecuária em plantio direto, submetido a intensidades de pastejo. Revista Brasileira de Ciência do Solo, v. 34 , p. $79-88,2010$ b.

VALOR bruto da produção agropecuária paranaense - 2008. Curitiba: Secretaria da Agricultura e do Abastecimento do Paraná, 2008. 37 p. 